\title{
2013 ASUU Strike Discourses in Nigeria: A Critical Discourse Analysis
}

\section{Crescentia Nwaeze Ugwuona}

\author{
Department of Linguistics Igbo and Other Nigerian Languages, University of Nigeria Nsukka, Nigeria
} crescentia.ugwuona@unn.edu.ng

\section{Doi:10.5901/mjss.2016.v7n2p435}

\begin{abstract}
Over a decade now, educational and socioeconomic developments in Nigeria have largely become trapped in a gap between language of truth and ideological use of the language in the discourses about (incessant) Academic Staff Union of Universities (ASUU) strikes. The ideologies in the 2013 ASUU strike discourses in Nigeria seem to be the highest since the history of ASUU strikes in Nigeria. Earlier researchers have investigated some discourses relating to 2013 ASUU strikes but the analysis on the embedded ideologies has hardly been examined properly. This study therefore seeks to identify and analyse some ideological use of the language in the 2013 ASUU strike discourses in Nigeria. Data were collected mostly from the web pages of the Internet: Through van Dijk's (2001) models of critical discourse analysis (CDA), the paper identify some mental models (ideologies) of language use in the discourses. The paper therefore recommends that language of truth in discourses, appropriate language use in print media by political commentators and newspaper columnists, and peaceful dialogue between the government and ASUU is pivotal in averting future ASUU strikes in Nigeria. The result of this study can have immediate application to areas of education, and socioeconomic development in Nigeria and beyond.
\end{abstract}

Keywords: 2013 ASUU strike, CDA, discourses, discourse analysis, van Dijk.

\section{Introduction}

Academic staff union of Universities (ASUU) in July 1, 2013 embarked on strike because of non implementation of 2009 agreement between the ASUU and the Federal government. This ugly experience lasted for six months and consequently generated a lot of concern among most Nigerians especially the stakeholders in the educational sectors. During the time, there was unbridled animosity, frustration, and anxiety among most Nigerians especially students, lecturers, parents, politicians, among others. Since then, ASUU strike discourses with its ideological leanings are couched and enshrined in internet and Nigerian print media but have passed unnoticed by many linguists. This paper therefore analyses five selected discourses about 2013 ASUU strike using insight from van Dijk's (2001) mental model of critical discourse analysis (CDA) to analyse the discourses. The paper derives data largely from Nigerian print media and the Internet about the ASUU strike discourses.

ASUU, Founded in 1978, through the instrumentalities of strike actions has often protested the government to respect the demands of the union. For instance, the union has used strike actions in the past to challenge the military regimes of General Muhammad Buhari, General Ibrahim Babangida and General Sani Abacha, the Kokori led NUPENG anti-June election annulment strike of 1994, Omar and Esele led anti-fuel subsidy removal general strike of 2012 (Ojonemi, P.S., Onechojon, U.T., and A .M. Attai 2013). Omidiora (2013) drawing from different statistics in Nigeria also observes that the history of ASUU strike in Nigeria dates back to post colonial era and has continued till date. In line with Omidiora, Aidelunughene (2014) notes that the National University commission (2002) reveals that ASUU have embarked on strike for more than twenty three (23) times since 1992. The union has also used strike actions to demand fair wages, University autonomy, funding of Nigerian federal Universities, among others. The above assertions suggest that strike actions in Nigeria have been a persistent challenge that seems to have defied solution since 1980. Despite earlier protests and advances by labour union (which ASUU is one) in quest of requesting the government to respect their demands, and to address ASUU strike actions in Nigeria, Nigeria is still enmeshed in the whirlpool of ASUU strikes. For ASUU to have embarked on another strike on July 1, 2013 because of non implementation of 2009 agreement between the ASUU and the Federal government depicts that the appropriate solution to ASUU strike has not been met, hence the need for this current study.

Over the years, there has been a rising interest in understanding how the analysis of discourses in Nigerian print media can foster socioeconomic and educational development in the country ( Agbedo and Ugwuona 2012, Okeke 2012, Ugwuona, 2015). A significant shortcoming of the existing literature is a lack of proper analyses of the language use as 
well as the embedded ideologies in the discourses about the incessant ASUU strikes in Nigeria. The few literature that exist lack critical discourse analysis on the discourses of ASUU strikes especially on the 2013 ASUU strike. Other researchers (Usman, Onechojon, and Attai 2013, and Famurewa 2014) recommend that the solution to the problem is that trade union should transform itself, making discipline as a watchword and design Nigerian peculiar theories reform; and by focusing on internally generated revenue projects. Though their study and the consequent recommendations are very interesting, it seems that the appropriate solution have not been met, hence, the need for this current study. We want to examine and analyse the language use in some selected discourses about the strike, and identify some obfuscate and ideological use of the language in the discourses. Additionally, national development is not only threatened by economic marginalisation, misappropriation of fund, insecurity, political exclusion, inadequate funding, among other, as earlier researchers (e.g. Aidelunughene 2014, Omidioara 2013) identified but also by ideological and manipulative use of the language in discourses. How then do we fully resolve the issue of ASUU strike in Nigeria in the contemporary times and enthrone peace, equity, education, and socioeconomic development. One of the significant answers to such questions is embarking on a study of 2013 ASUU strike discourses and analysing key ideologies and language use in the discourses about the strike; and suggesting also avenues for reconciling issues of language use in discourses so that an equitable integrity is sustained between ASUU and the FGN. Beyond that, analysing language use in discourses of the 2013 ASUU strike using CDA approach which often portrays hidden ideologies in discourses will go a long way in forestalling repetitious occurrences of ASUU strikes in Nigeria. It will also aid the commentators in Nigerian print media and the general public to consider the relationship between the words they choose to use in discourses and their implications. This will make for appropriate use of the language and go a long way in averting future ASUU strikes and as such, enhance national development at all levels. This paper therefore seeks to analyse the language use in the discourses of opinion writers and newspaper commentators on the issue of the 2013 ASUU strike in Nigeria using van Dijk's (2001) models of CDA. The analysis of the discourses would be in the sense of determining the ideological (mind control/mental models) features of the utterances and the pragmatic implications involved. That is, the style, rhetoric or meaning of texts for strategies that aim at the concealment of social power relations by playing down, leaving implicit of understating responsible agency of powerful social actors in the events represented in the texts. This will go a long way in identifying some cases of ideologies and manipulative use of the language in the selected discourses. Additionally, such will make for better understanding that appropriate language use by political and newspaper commentators is the major tool that will forestall incessant ASUU strike actions in Nigeria. In this way hopefully, the study must have contributed to the body of knowledge in the field of discourse analyses and a pointer on how to select appropriate language for use in newspapers and other situations both in talk and text. It will also open a gate way for further research in the field of critical discourse analysis of texts and language use by other researchers. At this juncture, it becomes pertinent to define some concepts that form the crux of this study, to situate it in its proper context.

\subsection{Conceptual framework}

In this section, we define some of the concepts for easy understanding of the work and as they apply to the current research.

\subsection{Strike}

Strike (Chijioke 2013) is an organised work stoppage by a body of workers to enforce compliance with demands made on an employer or a group of employers. Wikipedia has it that: strike action also called labour strike is a work stoppage caused by mass refusal of employees to attend to their work. A strike often takes place in response to the employees' grievances over some issues in their place of work. Most strikes called by unions are somewhat predictable; they typically occur after the contract has aspired.

According to Duhaime's Dictionary, strike is a term employed to denote a cessation of work or a refusal to work by a group of employees acting under a common understanding to compel an employer to certain terms. In this study, ASUU uses strike as a means to enforce the government to respect the demands of the Union.

\subsection{Discourse}

Crystal (1992:84) notes that 'discourse is a continuous stretch of (especially spoken) language larger than a sentence, often constituting a coherent unit, such as a sermon, argument, joke, or narrative'. Nunan (1993:6) states that 'discourse brings together language, the individuals producing the language, and the context within which the language is used'. 
Hence, the analysis of discourses is affected in the intellectual traditions that investigate and determine the relations among language use in discourses as in the field of sociolinguistics, sociology, etc.

\subsection{Ideologies}

Van Dijk (2001) defines ideologies as the basic social representations of social group which are at the basis of the knowledge and attitude of group such as socialists, neo-liberals, feminists, etc. Continuing, he remarks that ideologies feature the basic principles that organise the attitudes shared by the members of a group (van Dijk 2000). According to Wikipedia, Ideology refers to the system of abstracted meaning applied to public matters, thus making the concept central to politics. Implicitly in societies that distinguish between public and social life, every political or economic tendency entails ideology whether or not it is propounded as an explicit system of taught, he added.

\subsection{Theoretical framework:}

Critical discourse analysis (CDA) is adopted as the theoretical framework for this study. CDA has its roots in linguistics and sociolinguistics, and offers rich and stimulating empirical accounts of the role of language in the contemporary society. Van Dijk (2001) emphasises that CDA focuses on social problems, and especially on the role of discourse in the production and reproduction of power abuse or domination. He believes that wherever possible, it does so from the perspective that is consistent with the best interest of the dominated group. Van Dijk emphasises the role of sociocognitive, implicit or indirect meaning, subtle structures, mental model, context model, and event model in doing CDA. CDA research for him is interested in the study of ideologically biased discourses, and the ways these polarise the representation of us (ingroups) and them (outgroups), both at the level of global and local meaning analysis and overall strategy of positive self presentation and negative other presentation in which our good things and their bad things are emphasised, and our bad things and their good things are de-emphasised. He describes global meaning or superstructures as overall, canonical and conventional schemata that consist of typical genre categories as is the case for arguments, stories or news articles. While local forms are those of (the syntax of) sentences or formal relations between clauses or sentences in sequences: pronominal relations, active -passive voices, among others. Such global and local forms can also be observed in our sample discourses in this current study. Wooffitt (2005) notes that empirical work from CDA perspective largely draws upon what van Dijk (2001) has called a solid linguistic basis in that it often examines topics such as sentence structure, verb tense, syntax, lexical choice, the internal coherence of discourse, etc. In Holmes (2008) view, CDA approach seeks to identify ways in which readers or listeners are manipulated through choices of words and constructions to take a particular position in relation to the topic of discussion.

Van Dijk's (2001) critical discourse analysis is adopted as the theoretical method due to the merits it has over others. For instance, van Dijk's CDA as a research method centers on understanding the ideological machinations of discourse, and aims to produce a critique of how discourse operates to affect certain agendas especially in groups and political issues. In this respect, the objectives of critical discourse analysis, involve the laying bare of ideological agendas which emerge from the discourses produced in formal and informal exchanges. CDA also takes explicit position, and want to understand, expose, and ultimately resist social inequality, and wherever possible, it does so from the perspective that is consistent with the best interest of the dominated group.

The current study tends to identify such ideologies found in the 2013 ASUU strike discourses in Nigeria and analyses the ways some political commentators exercise power through such ideologies and manipulative use of language in their discourse.

\section{Literature Review}

Language use (Okeke 2012) does not simply involve encoding of messages or just attaining grammatical competence where every sentence would have a fixed interpretation irrespective of its context use, it also embodies the ability to use language accurately, appropriately, and flexibly to be communicative competent. Halliday (2003), as cited by Okeke (2013) remarks that language serves for making links with itself and with features of the situation in which it is used. This he calls text function which enables language users to construct texts or connected passages of discourse that are situationally relevant (and appropriate) and which are understandable (and acceptable) by the receivers. Ability to use language appropriately (Yule 2006) means that the user knows when and where to use language appropriately. For him, using language flexibly implies that the user has strategic competence to organise a message effectively and to compensate, via strategies, for any difficulties in what the speaker intends to express. These abilities in language use are 
the key elements in sociolinguistic communicative competence (Yule 2006, Ugwuona 2012). Johnstone (2008) laments that people do not actually appear to do what they do by using a body of language or knowledge of language or linguistic competence that they already possess rather, language seems to be created by speakers as they interact, noticing, repeating, and sometimes making reflective gerneralisations about what other people do, in the process of evoking and creating a world. For him, language no doubt, is a vital means human beings use in discourse and individual speakers learn to use it by speaking in the continual process of being and acting. His other emphasises is that CDA research is the study of the many forms of implicit or indirect meanings such as implications, presuppositions, among others. For him, implicit meanings are related to underlying beliefs, but not openly, directly, completely, or precisely asserted. CDA aims to investigate critically social inequality as it is expressed, signaled, constituted, legitimized and so on by language use (or in discourse) (Wodak 2001).

In his study of the application of political propaganda in 2013 FGN/ASUU conflict Ineji, Bassey-Duke, and Brown (2013) identified three major propagandas which the FGN employed to show that the political machination, contrivance, and subterfuge employed by the FGN were opulent and orchestrated to serve as a strategic political goal. Continuing, he observes that in a desperate effort to brainwash the public on all sorts of known and unknown, political propaganda strategies were employed to attract public sympathy. Similarly, in her study of Boko Haram discourses in Nigerian print media, Ugwuona (2015) discovered a lot of manipulative use of the language to cover the truth of the matter and recommends that manipulative use of the languages by some newspaper commentator and opinion writers can only bring rancor and confusion in Nigeria rather, the language of truth about Boko Haram insurgence in Nigeria and peaceful dialogue is the only weapon that will bring lasting peace and development in the contrary. See also Agbedo and Ugwuona (2010) for such studies on analysing discourses in Nigerian print media. In his analyses of, 'a petition against the persecution of Microsoft', van Dijk (2001) identifies some discourse structures to include implicit or indirect meaning, subtle structures, mental mode, social cognition, context model, and event model. He concludes that all these are geared towards reproduction of dominance and power abuse. Such discourse structures can also be observed in this current study as we shall observe in the subsequent sections. The forgoing suggests that to enhance success in language use, peace, progress, and meaningful developments in any given country, people should constantly and strategically figure out what to say, how to say things, and resorting to the language of truth and harmony in discourses

\section{Methodology}

The research methodology covers the research design and instrument, data collection, analysis, and limitations.

\subsection{Research design and instrument}

The research employs descriptive qualitative research methods given the fact that the data was in form of words not numbers.

\subsection{Data collection}

Samples of data were collected from the Internet which is currently one of the most powerful contemporary mass medium containing varying information, web-pages, and Nigerian online newspapers. The sample data include five sample discourses taken mainly from the Punch and other web pages in the Nigeria print media. From the data, the different ways mind control and ideologies are represented in the discourses were traced, analysed, and their significance were discoursed.

\subsection{Data Analysis}

The data is analysed using CDA model of analysis given the fact that it is an approach that is specifically interested in the discursive dimensions of language use in discourse especially as it concerns power abuse and dominance. Additionally, the choice is based on Van Dijk's (2001) assertion that critical discourse analysts take explicit position, and want to understand, expose, and ultimately resist social inequality, and wherever possible, it does so from the perspective that is consistent with the best interest of the dominated group. 


\title{
3.4 Limitation
}

A salient limitation of this study lies in the sample size and the type of discourses studied (CDA) which has to be interpreted with caution. Our data (only during 2013) are mainly from a few national online newspapers and web pages that raise questions of generalisation. Given the dynamics nature of language and discourses, future longitudinal studies would provide useful insights into how language use manifests on discourses in Nigerian print media over time.

\subsubsection{Significance of the CDA method}

As mentioned earlier, van Dijk's method of CDA is adopted for this study due to the fact that it takes explicit position, and wants to understand, expose, and ultimately resist social inequality, and wherever possible, it does so from the perspective that is consistent with the best interest of the dominated group.

In the following section, we will analyse the discourse strategies employed in the speeches of some political commentators as observed in Nigeria print media to show how the ideological processes (mental models) function in discourse to perpetuate power relations about 2013 ASUU strike.

\section{Analysing Data on 2013 ASUU Strike Discourses in Nigerian}

In this section, we analyse the discourse strategies where diverse linguistic and contextual choices contribute to power and dominance which could be considered related to the discourse of ideology, control and/ or mental model..

\subsection{Mental model}

Van Dijk's mental model as earlier said is observable in the news report on Nigaeduportal.blogspot, captioned "Okonjo Iweala says FG Can't meet Financial Demands of ASUU" by Okafor. In it Okonjo Iweala'a asserts:

\begin{abstract}
At present, ASUU wants the Federal Government to pay 92billion Naira extra allowances, when we are working to integrate past increase in pensions. We need to make choices in this country as we are getting to the stage where recurrent expenditures take the bulk of our resources and people get paid but can do no work.
\end{abstract}

In the sample discourse above, ideological propositions can be observed:

ASUU wants the Federal Government to pay 92billion Naira extra allowances, when we are working to integrate past increase in pensions. This statement depicts ideological expression which functions to control the minds of the general public, and make them to believe that ASUU is insensitive to the fact that the FG has no money since the FG is working hard to integrate past increases in pension. The schematic and ideological expression such as making explicit our good and their bad things are also observable in that first sentence of the stanza. That is, the federal government is working hard to integrate past increases in pension portrays the Government as doing good thing; and ASUU wants the Federal Government to pay 92billion naira extra allowance seeing that the federal government has no money, portrays ASUU as being inconsiderate in the minds of the readers of the text. The second sentence of the stanza depicts that the allowance ASUU is demanding has earlier been paid hence, the statement: We need to make choices in this country as we are getting to the stage where recurrent expenditures take the bulk of our resources... this statement has other implications as it expresses the ideological perspective of the speaker, that is, the action of the ASUU is defined in negative terms, implying a form of moral or legal justification of the action of the FGN by not being able to meet the demands of the ASUU. The choice of the construction when we are working to integrate past increases in pension also contributes to the organisation of the local meaning, implying that the FGN is working hard which can be seen in the integration of past increases in pension. The choice of this structure: People get paid but can do no work functions to showcase ASUU as being paid but do not work. The lexical selection here shows the familiar form of negative other presentation, and positive self-expression. In more cognitive terms, the choice of the speaker's words functions to influence the formation of bad opinion about ASUU in the mental model of the readers of the text and the public.

The discourse also conforms to van Dijk's idea of ideology where discourse may emphasise our good things by topicalising positive meanings, using positive lexical items in self-description, providing many details about good actions, and few details about bad actions. Such formal and meaning aspects of dominant discourse not only express and enact power but are also geared to the construction of desired mental models and social representations to influence manipulations or control of the mind as shown above. 


\title{
4.2 Context model
}

Van Dijk notes that context model is discourse structures that are related to structures of local and global contexts. Here, global contexts are defined by the social and political structures in which a communicative event takes place, and they form the ultimate explanatory rationale and critical rationale of discourse and its analysis. While local context is usually defined in terms of properties of the immediate interactional situation in which a communicative event takes place. Properties of such a situation as he explains are its overall domain (politics, business), an overall action such as legislation, propaganda. Such can also be seen in the report of Niyi on October 15, 2013 on Information Nigeria how traders under the aegis of National market women association stormed the National Assembly in protest demanding that the ASUU call off its strike of over 100 days, in the following discourse:

We are tired of seeing our children at home. We want our children back in school. Enough of this cheap blackmail.

We all know what they do with our year-one daughters in the University. We equally know that they sell handouts and handbooks.

Is this not worse than corruption of the highest order?

\begin{abstract}
... How do you expect lecturers in state Universities to earn same salaries as Federal ones? This is impossible. We are not educated but you do not expect a hotel in my village to cost same price as a hotel in Abuja.
\end{abstract}

We are begging them for the last time. If we come out again, we may have to chase them out of this country and replace them with so many jobless Nigerians.

The expressions above align with van Dijk's assertion that context model are the mental representations that control many of the properties of discourse productions and understanding such as genres, topic choice, local meaning and coherence, that is, discourse structures are related to structures of local and global contexts. Here, mental models not only represent personal beliefs, but also social representations, such as knowledge, attitudes and ideologies, which in turn are related to the discourse of group and organisations.

In the second stanza, knowledge or attitude items which expresses directly in their general abstract forms in the generic sentences typical of propaganda can be observed. For instance, in the expression, we all know what they do with our year-one daughters in the University. We equally know that they sell handouts and handbooks, expresses generic sentences typical of propaganda. At the same time, through schematic representations of their personally and group knowledge, attitudes and ideologies, the expression aims to influence the opinion of the masses about the ASUU by polarising and propagating the negative other (ASUU) group.

In the third stanza, the expression functions to control the minds of the readers of the text and attract their sympathy and that of the general public, since even the market women are protesting against the ASUU and demanding that the ASUU call of its strike. The discourse explicitly represents the voice of the market women but implicitly and schematically represents the voice of the government. Hence, the expression: How do you expect lecturers in state Universities to earn same salaries as Federal ones? This is impossible.

In stanza four, the expression: 'We are begging them for the last time. If we come out again, we may have to chase them out of this country and replace them with so many jobless Nigerians', implies that the actual source of the information is not explicitly expressed but presupposed by the text, suggesting that the hand of the government was behind the women association's action, while the expression is implicitly organised by the market women ideology. At the same time, the expression aims to influence the mental (opinion) models of the general public and the masses that even the market women are genuinely concern about the plight of parents and the students who are mostly affected by the prolonged strike. In the protest text, the market women are defending the FGN and attacking the ASUU by advocating that: If we come out again, we may have to chase them out of this country and replace them with so many jobless Nigerians. Obviously, such sociopolitical assertion suggests the government shared beliefs which are not explicitly expressed but presupposed by the text. In the text above, it can also be observed at all levels of the text how the negative opinion about the ASUU is linked to the group of the market women ideology who they refer to as being corrupt.

Basically, the discourse adopts van Dijk's subjectively construed context model of the current communicative situation such as:

- The local setting of the communicative event is the National Assembly.

- The context and defining the communicative event is that of the FGN and the ASUU strike.

- The societal domain for the discourse is that of education and socioeconomic development, and the 
government.

- The genre and the communicative role of the participants is one form of implementing the overall defense of the FGN and as an opponent of the ASUU which seem to be the global aim of the discourse.

\title{
4.3 Mental model
}

Speaking on the ongoing strike of the Academic Staff Union of Universities at a press briefing with Daily Post Magazine during MUAA award ceremony at the Ladi Kwali Hall, Sheraton Hotel, Abuja, Chuma Achu, President of the Madona University Alumni Association, MUAA says:

The Madonna University Alumni Association (MUAA) has condemned the ongoing strike by the Academic Staff Union of Universities, ASUU saying that its demand of close to 3 trillion naira was unrealistic.

\begin{abstract}
...the issue of decay in the education system is something that has happened over a period of time. It was a known fact that budgetary allocation to education in the last 25 years has been quite less than the standard set by the education in the United Nations; hence, you don't expect the current administration to mop up those lapses just instantly. It will take time to get this done as it requires systematic approach .... Asking the federal government to cough out almost trillion naira as a last option is a wild goose chase and totally unrealistic.
\end{abstract}

In the sample text, mental model can be observed. For instance, it can be observed that the repeated use of passive constructs that typically hide agents such as, the issue of decay in the education system is something that has happened over a period of times: obviously function to omit the agents of negative actions. This conforms to Van Dijk's (2001) assertion that ... negative properties of us (or those we defend) are either omitted or downgraded in the text. That is, theoretical omission is only a relevant property of a discourse when it can be shown that the omitted information is part of the mental model.

The genre and the speech act of the MUAA President, in the expression: "...Asking the Federal Government to cough out almost 3 trillion naira as a last option is a wild goose chase and totally unrealistic" is one form of implementing the overall defense of the government's (ingroup) action. In the assertion: The amount is equivalent to a nation's total budget and not realistic at all presupposes that the MUAA President and his subjects are supporting the government. The expression also conforms to Wooffitt 's (2005:40) assertion, 'that ideologies serve to protect the interest of the powerful groups and ensure that certain events, ways of acting and relationships come to be regarded as legitimate or appropriate.' The sample text also relate to van Dijk's view, that discourses are interpreted as coherent relative to the mental models the language users have about the events or facts referred to. For instance, this assertion: ...the issue of decay in the education system is something that has happened over a period of time. It was a known fact that budgetary allocation to education in the last 25 years has been quite less than the standard set by the education in the United Nations; hence, you don't expect the current administration to mop up those lapses just instantly, depicts the obviously biased ways the MUAA represents this case and the organisation's mental model of these events which serve to portray ASUU negatively, that is, the global aim of the assertion.

In a report entitled "Jonathan considers Thatcherite anti-union laws to break ASUU strike" the writer reports the president's speeches about ASUU strike during a presidential media chat in Abuja on National Television Authority (NTA) on Monday, 30 September, 2013. The writer reports the President's speeches thus:

Several meetings to resolve the impasse have failed and it appears that the government is now considering introducing Thatcher-like legislation to break the strike.

It was inconceivable that lecturers in state-owned universities would go on strike over issues concerning the allowances of lecturers in federal universities. ... Such a situation would not occur if well-guided and well-thought out laws were in place regulating labour union activities.

My administration has done all within its power to meet the demands of the university lecturers. This includes setting up a technical committee to carry out inventories of the universities while it has also set aside $N 100 \mathrm{~m}$ for the provision of infrastructure in the tertiary institutions which is one of ASUU's key demands.

The meaning of the text is understandably within the broader framework of the domain of law and strict condition. The polarization of the provisions of the government to ASUU depicts the ideologies of the government and functions to influence the readers of the text and the public. In the second paragraph, the use of the passive voice (is indicated) 
removes any reference to the actor or agent, thus enables the reporter to avoid allocating explicit responsibility to the Government. The assertion "... such a situation would not occur if well-guided and well-thought out laws were in place regulating labour union activities, presupposes that well-guided and well-thought laws were in place to regulate labour union activities in Nigeria. My administration has done all within its power to meet the demands of the university lecturers, functions to position President Jonathan's administration positively. We can also notice ideological objectives or implicit meaning in the last paragraph to emphasise our good thing and their bad thing.

In another report by Blog spots on Thursday 3, October 2013, titled: ASUU: FG begs Nigerian Union of Teachers to withdraw strike threat. In it, the Supervising Minister of Education, Mr. Nyesom Wike at a news conference in Abuja on the proposed solidarity industrial action by the NUT, on behalf of the Federal Government appeals to Nigerian Union of Teachers (NUT) to shelve its proposed solidarity with ASUU. His words:

The 2009 agreement with ASUU have a number of issues and I want to tell you that the Federal Government has already met 80 per cent of the critical needs. It is remaining only two components which are earned allowances and they are expecting the Federal Government to release 400 billion annually for infrastructural development. ASSU now asked the federal Government to develop the Universities annually and it shouldn't be part of Tertiary Education Trust Fund TETFund and that the Federal Government should allocate $\$ 400$ billion for capital projects in the Universities. This is not realistic because we have polytechnics and colleges of education....

It can be asserted that the sample text above conforms to van Dijk's (2001) well-known ideological objectives which serve to emphasise our good things (ingroup) and their bad things (outgroup). This is very glaring in the above discourses of the education Minister (in-group) who seems to be emphasising the good things of the government and the bad things of the ASUU (out-group). The discourse also functions to misrepresent the ASUU's actions which clearly contribute to sustaining unequal relations of power between the ASUU and the Government hence, the expressions depict ideology.

\subsection{Event model}

Event model is observable in a report by Premium Times on October 24, 3013 on the caption: Those That Signed Agreement with ASUU Don't Know Their Right from Their Left. In it, the Senate President, David Mark while ruling on a motion on a plenary of the Senate brought by the Senate leader, Victor Ndoma-Egba and co-sponsored by all the Senators, reports:

\footnotetext{
Listening to the agreement that was signed by the Federal Government, as comrade Uche Merije reads out, I was really wondering whether this was agreement or it was just a proposal. But when he concluded, he said it was signed. It only shows the level of people the executive sent to go and negotiate on their behalf because abinitio, people must be told the truth, what can be accomplished and what cannot be accomplished. If a leader says I am going to accomplish this, he is morally duty bound to honour it. But even if you decided immediately after that you cannot accomplish it, I think it is only proper for you to go back and start renegotiating. ... I think ASUU simply took advantage of the ignorance of those we sent and simply just allowed this agreement to go on because it is obvious that this is going to be difficult piece of paper to implement. They found that those who were sent there simply didn't know their right from their left and they just went ahead. I think that also is not fair because ASUU is an organization in Nigeria and we are not going to another country to implement this piece of paper.
}

In the sample discourse, the expressions by the Senate President relates to Van Dijk's event model where facts are defined or interpreted by language users in their mental models of these facts, and interpretation of facts is personal, subjective, biased, incomplete or completely imaginary. The discursive control of preferred mental models in the effort to control the minds of the public and attract sympathy can also be observed in the assertion, for instance: I think that also is not fair because ASUU is an organization in Nigeria and we are not going to another country to implement this piece of paper. The obvious function of the statement is mind control of the public and the readers of the text and thereby attracts public sympathy towards the issue that the basis upon which the agreement was reached did not reflect fairness and sincerity of purpose on the part of the ASUU. Another important structure that deserve attention in the text is the complex argumentative framework in which ideological principles function as general argument and their applications to the ASUU demand with the assertion: I think ASUU simply took advantage of the ignorance of those we sent and simply just allowed this agreement to go on because it is obvious that this is going to be a difficult piece of paper to implement. 


\title{
4.5 Context model
}

In online news of December 92013 captioned: President Jonathan is Nigeria's Mandela, context model of discourse can be observed. In it, Doyin Okupe a political appointee in President Jonathan's administration, during an interview he granted AIT on December 6, 2013 reports:

\begin{abstract}
Nelson Mandela was a great leader. He lived his life for the people of South Africa. I check through the history of Nigeria among the past and present leaders, the only one we can call our Mandela here in Nigeria is President Jonathan. There is no any President in Nigeria that has sacrificed 13 hours to discourse with ASUU...
\end{abstract}

The expression above conforms to van Dijk's (2001) subjective construed context model of discourse in which mental representations control many of the properties of the production and understanding such as genre, topic choice, local meaning and coherence; which are the kind of personal, subjective mental models that characterise discourse. Such personal subjective mental models can be observed in the speeches of Doyin Okupe in the above discourse: "I check through the history of Nigeria among the past and present leaders, the only one we can call our Mandela here in Nigeria is President Jonathan. There is no any President in Nigeria that has sacrificed 13 hours to discourse with ASUU...' The expression depicts van Dijk's social cognition where mental structures control the production and comprehension of text and talk. Such control takes basically two forms, a direct or an indirect form for instance, in generic sentences typical of propaganda. In the Okupe's assertion, such generic forms of knowledge or opinion such as: the only one we can call our Mandela here in Nigeria is President Jonathan. There is no any President in Nigeria that has sacrificed 13 hours to discourse with ASUU...' can be observed.

\section{Summary, Conclusion and Recommendations}

This paper analysed selected discourses on 2013 ASUU strike discourses in Nigeria from the insight of van Dijk's three major models (mental, context and event models) of critical discourse analyses. The study identified some manipulative, ideological, and schematic use of the language which seems to obfuscate the truth of the matter by political commentators. The study argues that the incessant ASUU strikes in Nigeria since post independence till date can be trapped by language of truth and appropriate use of the language in discourses about ASUU strikes by newspaper and political commentators in Nigerian Print media. Since the 2009 agreement that resulted in 2013 ASUU strike, ASUU and the FGN has been at crossroads. The overlap in the agreement and fulfillment of the 2009 FGN and the ASUU agreement will continue to linger if language of truth, peaceful dialogue, and polite language use between the FGN and the ASUU is not embraced. Manipulative and ideological use of language in discourses by political commentators in the Nigerian print media in the effort to control the minds of the public and attract sympathy can only bring rancor, confusion, and even increase strikes in Nigeria. The study therefore recommends that ASUU as well as FGN officials need to acknowledge the fact that strike is an evil wind that retards educational and socioeconomic development in any affected country especially Nigeria. Consequently, there is urgent need for language of truth, unity, love, and polite language use by newspaper and political commentators by every average Nigerian, including the FGN, and the ASUU, as such remain the best options in averting ASUU strike at any point in time in Nigeria. Besides, peaceful environment as imbedded in appropriate language use in our educational systems is pivotal in securing the ecological educational, socioeconomic, political, and overall development in Nigeria.

\section{References}

Adoyi, M.A. (2013). ASUU strike: Union's demands unrealistic. In: Daily Post Nigerian Newspaper. [Online] Available: http://myschool. com.ng (October 8, 2013).

Agbedo, C.U.\& Ugwuona, C.N. (2010). Yar'Adua Cabal as a Discourse Topic in Nigerian Media Political Discourse. In: International Research and Development Institute: Proceedings of the sixth International Confference on Sustainable Development: 68-77.

Aidelunughene O.S. (2014). ASUU industrial actions: Between ASUU and Government is it an issue of rightness? In Journal of Education and Practice. Volum 5. No 6.

Crystal, D. (1997). The Cambridge encyclopedia of language. Cambridge: Cambridge University Press.

Duhaime Dictionary. [Online] Available: http://www.duhiame.org/legalDictionary (July24, 2015).

Fairclough, N. (1989). Language and power. London: Longman.

Fairclough, N. (1995). Critical discourse analysis: The critical study of language. Harlow: Longman.

Famurewa, I.O. (2014). Inadequate funding as the bane of Tertiary education in Nigeria. In: Greener Journal of Economics and Accountancy. [Online] Available: www.gjournal.org (July24, 2015). 
Holmes J (2008) An introduction to sociolinguistics. Edinburgh: Person Education Ltd.

Johnstone, B. (2008). Discourse analyses. USA: Blackwell Publishing.

Meyer, M. (2001). Between theory, method, and politics: Positioning of the approaches to CDA. In: R. Wodak and M. Meyer (Eds). Method of critical discourse analysis: London: SAGE Publications, pp.14-31.

NiajaGist.com (2013) ASUU strike: President Jonathan is Nigeria's Mandela- Doyin Okupe tells AIT. [Online] Available: www.naijagists. com (September 18, 2015).

Nyesom, W. (2013). FG begs Nigerian Union of Teachers to withdraw strike threat. In: Blog Spots. [Online] Available: http://blog.org (October 3, 2013).

Ojonemi, S., Onechojon, U.T. et al (2013). Labour Unions and the transformation of the Nigerian civil service: A discourse analysis. In: International Journal of public administration and management research (2). [Online] Available: http://www.rcmss.com (July24, 2015).

Okafor, C. (2013). Okonjo Iweala says FG can't meet Financial Demands of ASUU. In: Blog Spots. [Online] Available: www.naijaedupotal.blogspots.com (August 14, 2013).

Okeke, F.A. (2012). Language can: Ensuring national security through effective use of language. In: International multidisciplinary Journal, Ethiopia: (4) pp.216-233. [Online] Available: http://dx.doi.org ( September 18, 2015).

Olusegun Fapohanda (2013). Excerpts of the 2009 Agreement between Federal Government and ASUU. [Online] Available: http://org.channelstv.com (December 15, 2013).

Omidiora, M. (2013). History of ASUU strike in Nigeria. [Online] Available: http://www.osundefender.org (September 25, 2013).

Ugwuona, C.N. (2012). Fuel subsidy in Nigeria: A discourse analysis. In: International Journal of advancement in development studies (6) $2276-8246$.

Ugwuona, C. N. (2015). Boko Haram as a discourse topic in Nigerian print media from 2010-2012. In :International Journal of culture, Society and Development (5) 53-57.

Van Dijk, T.A. (2000). Ideology and discourse: A multidisciplinary introduction. Pompeu Fabra University, Barcelona. [Online] Available: http://www.discourses.org (Septembe 7, 2014).

Van Dijk, T. A. (2001). Multidisciplinary CDA: A plea for diversity. In: R. Wodak \& M. Mayer (Eds.) Methods of critical discourse analyses. London: SAGE Publications, pp.95-120

Wikipedia. [Online] Available: https://en.m.strike.wikipedia.org (October 7, 2014).

Wodak, R. (2001a). What CDA is about: A summary of its history, important concepts and developments. In: R. Wodak \& M. Meyer (Eds.) Methods of critical discourse analysis. London: SAGE Publications.

Wodak, R. (2001b). The discourse historical approach. In: Wodak R and Meyer M (eds) Method of critical discourse analysis, PP.14-31. London: SAGE Publications.

Wooffitt R (2005). Conversational analysis \& discourse analysis. London: SAGE Publications.

Yule, G. 2006. The study of language. Cambridge: Cambridge University Press. 